\title{
Help us find and honour the stars of South Asian healthcare
}

The prestigious BMJ Awards are back in the Indian subcontinent, and this year they promise to be even bigger and better, writes Jeetha D'Silva. Submit your nominations now at http:// southasiaawards.bmj.com-and good luck!

Jeetha D’Silva journalist, Mumbai

The BMJ Awards are back in the Indian subcontinent for 2015, rebranded as the BMJ Awards South Asia. This year nominations are invited from eight countries-Bangladesh, Bhutan, India, Maldives, Myanmar, Nepal, Pakistan, and Sri Lanka. And there are new categories, including awards dedicated to the specialties of cardiology, pulmonology, and diabetes; one for an outstanding postgraduate thesis; and one to recognise exceptional journalism.

The aim, as always, is to identify and to honour the doctors and other healthcare practitioners striving to improve healthcare delivery and medical research in the region.

\section{"The Oscars of medicine"}

The BMJ Awards launched in the United Kingdom in 2009. Dubbed the "Oscars of medicine," they have become a coveted prize in medicine. ${ }^{1}$

The BMJ Awards India was launched last year. Doctors throughout the country participated, culminating in an awards ceremony on 20 September 2014 in New Delhi. More than 500 high quality nominations were received among the 10 categories. $^{23}$

"The awards reflect our desire to recognise and highlight excellence in the practice of medicine in South Asia," said Prashant Mishra, the managing director of BMJ India.

\section{Prominent platform}

The winners of last year's awards said that the accolade gave them a prominent platform on which to showcase their work. Anuradha Rose, associate professor of community medicine at the Christian Medical College in Vellore, Tamil Nadu, described the 2014 BMJ Awards India as "quite brilliant."

Rose's Jawadhi Hills Health and Development Project won in the Primary Healthcare in Challenging Circumstances category. The project focuses on improving healthcare services among the tribal communities of the Jawadhi Hills, a remote region of the Nilgiris in south India.

"The awards have brought greater visibility to the work done by our team," she told The BMJ. We now have many more people who are keen to help us with personnel and funds, Rose added.

\section{"A lot of recognition"}

Sarman Singh, another 2014 winner and clinical microbiology professor at All India Institute of Medical Sciences in New Delhi, said that entering the awards had been a great experience and that after winning his work had received "a lot of recognition."

Singh won the award for Innovation in Healthcare Technology for developing a cost effective diagnostic test for visceral leishmaniasis, a neglected disease that kills about 50000 people a year worldwide.

Other winners last year included teams from eminent institutions such as the Jawaharlal Institute of Postgraduate Medical Education and Research in Pondicherry; Fortis Hospital in Mumbai; Apollo Hospital in New Delhi; the All India Institute of Medical Sciences in New Delhi; and the Amrita Institute of Medical Sciences in Kochi. ${ }^{3}$

\section{Specialty awards}

The overwhelming response to last year's awards was the key reason for expanding the geographical scope of the 2015 awards, Mishra said. The number of categories has also been increased to 12 .

The huge burden of diabetes and cardiac and respiratory diseases in South Asia has prompted dedicated awards this year to recognise the specialty teams striving hardest to make care accessible and affordable. 


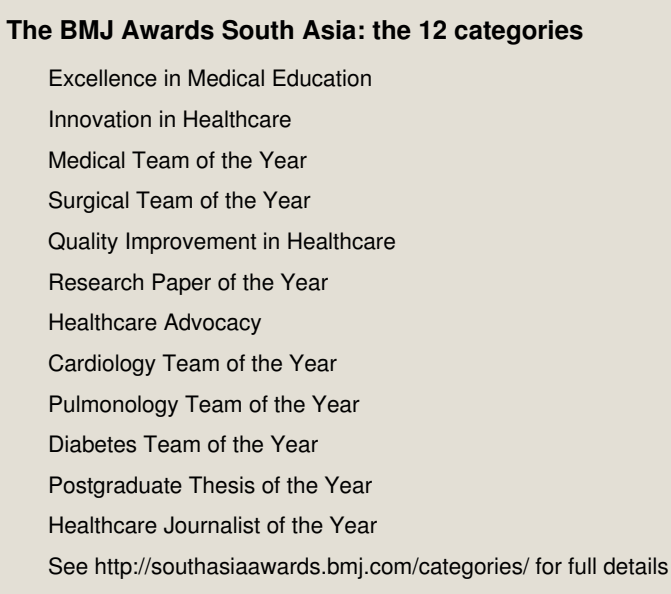

Also new for 2015 is an award for an outstanding postgraduate thesis. "This very important activity ... forms the backbone of clinical research in our region," the organisers wrote. Healthcare journalists are also to be honoured, with a category to recognise their "crucial role in empowering people, guiding national policy, and shaping mass opinions."

Nominations are now open, and applications can be submitted through the BMJ Awards South Asia website (http://

southasiaawards.bmj.com), which also gives more details about the categories, the judging process, and timings. ${ }^{4}$ Nominations must be submitted by 30 July 2015, and the first stage finalists will be announced on 21 August.

\section{Judging nominations}

In the first round of selection, the BMJ team will sort through the nominations. "We will be looking at the local and regional relevance of the work and how well it addresses the defined problem," said Prashant Jha, senior editor at The BMJ India. "In addition, we will consider scalability and we will also rate nominations for novelty." About 10 nominations will be shortlisted for each category.

For the next phase of judging, the shortlisted nominees will be asked to submit documentation in support of their nomination. This will start on 21 August and close on 10 September. Successful nominees will be announced on 21 September.

These finalists will present in person to a jury on Thursday 29 October in Mumbai. The jury will comprise experts in medical practice and research and academics and will include specialists related to all the award categories.

For the 2014 awards jury members included Nata Menabde, the World Health Organization's representative to India; Velu Nair, dean at Pune's Armed Forces Medical College; and Prabhakaran Dorairaj, vice president of the Public Health Foundation of India and director of the Center for Cardio-metabolic Risk Reduction in South Asia.

The 2015 winners will be announced on 30 October 2015 at a ceremony at The Leela hotel in Mumbai before a select audience of healthcare professionals from throughout South Asia.

\section{Already generating interest}

The awards are already generating interest in the South Asian medical world. "The BMJ South Asia Awards will encourage more doctors to go and serve in rural areas," said Bikash Gauchan, medical director at Possible, a non-profit company that delivers high quality, low cost healthcare to poor people in rural Nepal.

The company is currently involved in rebuilding Nepal's healthcare system after the devastating earthquake that struck on 25 April. Gauchan told The BMJ that his team at Possible is considering entering the awards.

Sayeba Akhter, an obstetrician and founder of MAMM's Institute of Fistula and Women's Health in Dhaka, said that the BMJ South Asia Awards will go a long way to let the international community know about the hard work and the effort that doctors in South Asia put in. MAMM's Institute-an initiative for women suffering from obstetric complications, such as obstetric fistula, female genital prolapse, perineal tear, vaginal stenosis, and other birth related complications-has been nominated for the Surgical Team of the Year category.

Competing interests: I have read and understood BMJ policy on declaration of interests and have no relevant interests to declare. For further information see http://southasiaawards.bmj.com or email southasia.awards@bmj.com

Follow us on Facebook (fb.com/BMJIndia) and Twitter (@BMJIndia), with hashtag \#BMJAwardsSA15

Provenance and peer review: Commissioned; not externally peer reviewed.

1 Hurley R. The "Oscars of medicine" are coming to New Delhi: who will you nominate as a hero of Indian healthcare? BMJ 2014;349:94540.

D'Silva J. Judging the best of Indian healthcare. BMJ 2014;349:95454.

3 Hurley R. The BMJ Awards India: And the winners are ... robotic spinal surgery, hospital stewardship of antibiotics, and primary care for hill tribes. BMJ 2014;349:95803.

4 BMJ. Announcing the launch of BMJ Awards South Asia. June 2015. www.bmj.com/ company/wp-content/uploads/2015/06/south-east-asia-awards-2015.pdf.

Cite this as: BMJ 2015;350:h3426

๑ BMJ Publishing Group Ltd 2015 